\title{
GEOPHYSICS APPEARANCE OF THE SOUTH CHINA SEA
}

\author{
Eddy Mirnanda \\ Marine Geological Institute of Indonesia (MGI) \\ Jalan Dr. Djundjunan No. 236, Bandung, 40174, Indonesia \\ eddy.mirnanda@esdm.go.id
}

Received 25-11-2021, Revised 01-09-2021, Accepted 07-09-2021, Published 1-10-2021

\section{ABSTRACT}

South China Sea (SCS) is underlain by sediments of an average density $2.10 \mathrm{~g} / \mathrm{cm}^{3}$ of $2 \mathrm{~km}$ thickness at its central part up to $10 \mathrm{~km}$ in the margins. The basement rock is the upper and lower crust of densities 2.67 and $2.85 \mathrm{~g} / \mathrm{cm}^{3}$ respectively of varying thicknesses. The thinnest crustal rock is at the centre of SCS that is called the South China Sea Basin (SCSB). The Mohorovicic discontinuity is about $15 \mathrm{~km}$ depth below the SCSB. Heatflow values in this basin vary from 2 to $3.5 \mathrm{HFU}$.

Lineations of total magnetic anomaly are generally in a west-east direction covering the whole study area. However, an elongated northeast-southwest lineation of dipole anomaly separates the west-east anomaly patterns in the north from those in the south. This feature is also observed in the gravity map. These elongated patterns of the total magnetic features are in coincident with the occurrences of seamounts inferred being remnant of extinct seafloor spreading. Because of this spreading a crustal extension had taken place that separated Kalimantan from the mainland of China to restore its present position. A paleomagnetic study result confirms this hypothesis.

The Palawan trench is marked by north-east trending magnetic and gravity anomaly that is inferred being traces of a remnant subduction zone. This anomaly forms a boundary between the Zengmu also called the Sarawak basin and the SCSB. Here, heat flow value is 1 to $2 \mathrm{HFU}$. This value in coincident with gravity gradient of $2.5 \mathrm{mGal} / \mathrm{km}$ also represents an active subduction of the Manila trench north of the Palawan Island. The Manila trench is supposed to be the energizing source of volcanism and earthquake in the Phillippines. Free-air and Bouguer anomaly of the order of 50 to $60 \mathrm{mGal}$ and magnetic of about $100 \mathrm{nT}$ represent the Zengmu basin in the Sunda Shelf. This basin is underlain by sediments of $2.10 \mathrm{~g} / \mathrm{cm}^{3}$ of $8 \mathrm{~km}$ thickness and also crustal rock which is much thicker than the one underneath the SCSB. Strong topographic relief at the surfaces of sedimentary layer and the crustal rock is very my much associated with normal faulting that may cause fluctuation of the free-air values.

The continental margins of Sarawak and the Sunda Shelf are areas of hydrocarbon deposits now still in production, whereas the offshores Vietnam and Hainan are promising target for hydrocarbon exploration.

Keywords : South China Sea (SCS), geophysics appearance, South China Sea Basin (SCSB), Serawak Basin, Zengmu Basin, magnetic and gravity anomaly, Heatflow. 


\section{INTRODUCTION}

The survey area is a part of South China Sea (SCS). In the North and West it is bordered by the passive continental margin of Asia and in the East by the active Manila and Luzon subduction zone (Figures 1 and 2). In the South the area is bordered by the Kalimantan Island and the Malayan peninsula and Sumatra. The central part of the investigated area is a basin with a water depth of $3000 \mathrm{~m}$. North and South of the basin is a shelf area of about 200 meters of depth.

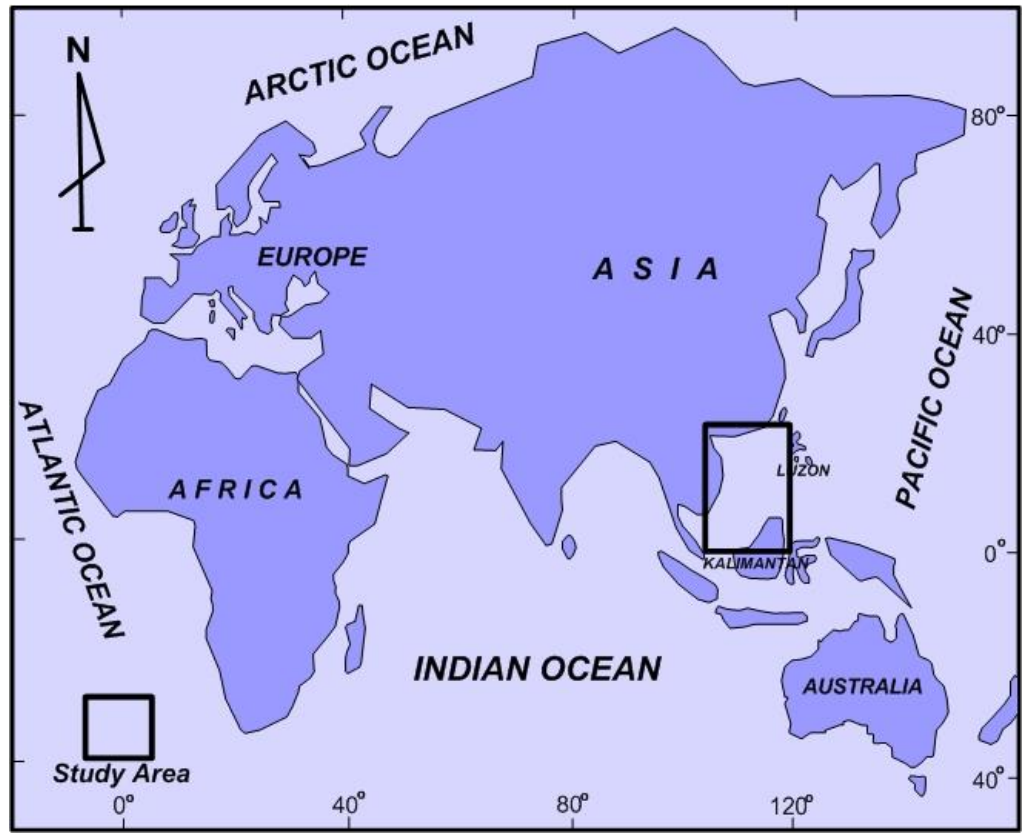

Figure 1. Location Map of South China Sea (SCS)

Previous authors, among others, Karig (1971 and 1973) ${ }^{[1,2]}$ classified the area as a nonactive basin marked by a slightly higher heat flow than the normal value ${ }^{[3]}$. This was formed as an interactive basin of the Philippine arc during Late Cretaceous until early Tertiary time. Taylor and Hayes (1980) ${ }_{24}^{4]}$ based on their analyses on magnetic data, concluded a northeast-southwest symmetric pattern of anomaly marked the existence of an ocean floor spreading which was active during middle Oligocene towards the early Miocene ${ }^{[5]}$. Xia Kan-Yuan and Zhou Di (1992) ${ }^{[6]}$ reported 40,000 gravity and magnetic readings were made in the north and south of the basin, $10,000 \mathrm{~km}$ multi channel seismic were shot, and 20 sonobouoy refraction seismic and 5 stations heat flow measurements were made. The results of these surveys are as follows: 1) the continental margin in the northern part of the basin is diverging, whereas in the south is converging; 2) the gravity and magnetic anomaly in the northern margin mark a pre-Tertiary basement, especially the free-air anomaly is very related to basement undulations. In the south, on the other hand, the crustal rocks become thinner with lower magnetization. 


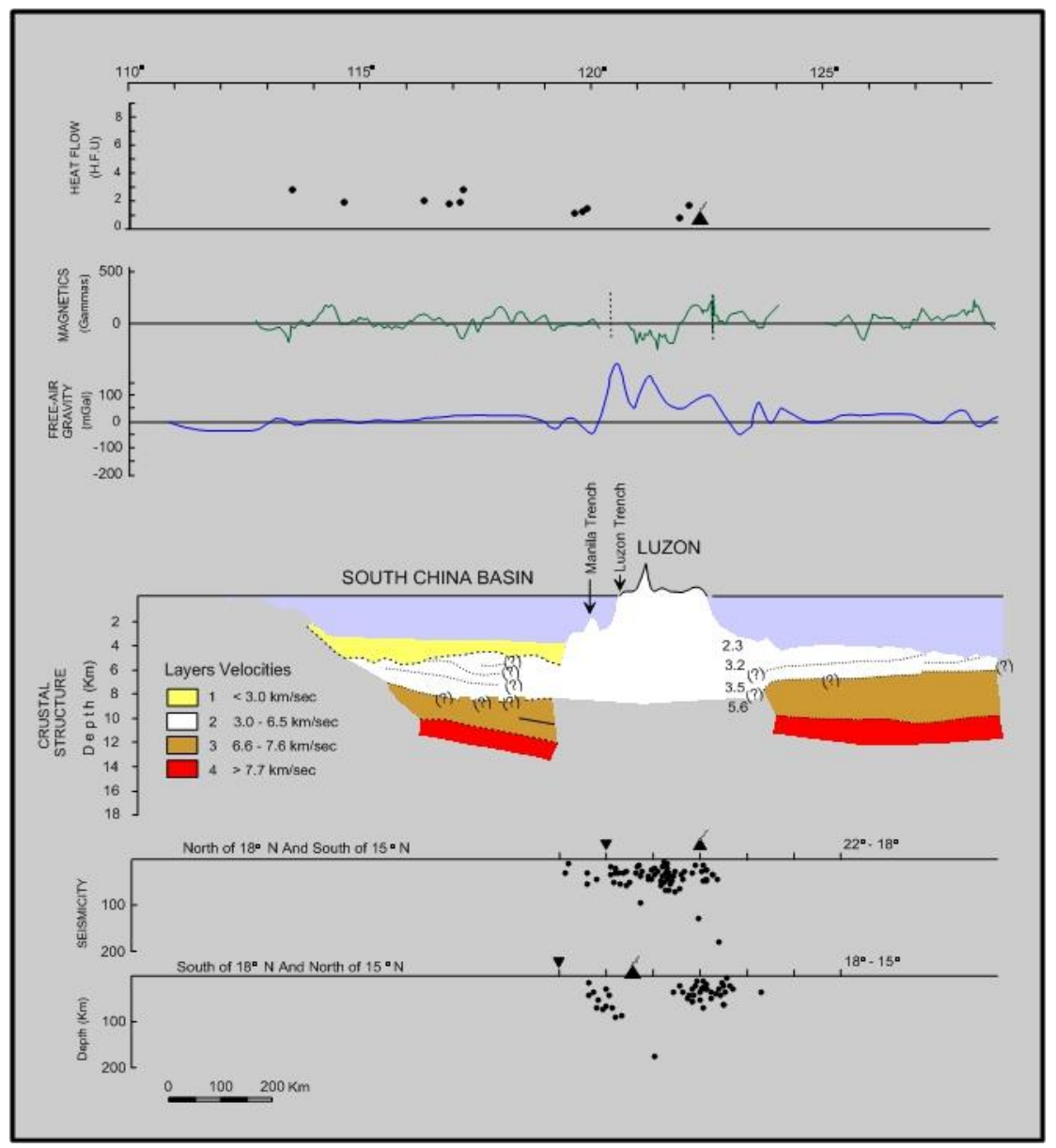

Figure 2. $2000 \mathrm{~km}$ west-east geophysical profile crossing the South China Sea towards Luzon showing heat flow, magnetic, free-air gravity, subsurface geology and seismicity ${ }^{[7]}$.

A west-east geophysical profile crossing the SCS from the shoreline of Vietnam to the island of Luzon, the Philippines ${ }^{[7]}$ (Figure 2). Sediments of $3 \mathrm{~km} / \mathrm{s}$, crustal rocks of 3.0 to $6.5 \mathrm{~km} / \mathrm{s}$ and the mantle rocks of $7.7 \mathrm{~km} / \mathrm{s}$ seismic velocities are underlying the basin. Seismic centers are located in the seismic belt of the Manila Trench. This paper was compiled based on the Indonesian Gravity Map (IGC or Indonesian Gravity Commission, and GETECH, 1994) and the free-air map of Bowin (1982) ${ }^{[8,9]}$. The gravity of the Nansha islands, an area bordered by longitude $106^{\circ}$ to $118^{\circ} \mathrm{E}$ and $4^{\circ}$ to $15^{\circ} \mathrm{N}$, was reported by $\mathrm{Su}$ Da Quan, et al., (1995) ${ }^{[10]}$. They divided the area of investigation into three provinces, namely: 1) the Serawak Basin in the Sunda Shelf marked by gravity features controlled by variation of sediments thickness. This basin is characterized by variation of anomalies, that is high value of anomalies are inferred being caused by a thinning of the crustal rock so that local thickening of sedimentation had taken place, whereas the low anomalies with long wavelength are regional in character; 2) high anomaly as large as $100 \mathrm{mGal}$ of the Reed Bank. This high is a representation of a continental crust which exposed on the sea surface. The boundary of the continental and the oceanic crust is marked by positive anomaly of $50 \mathrm{mGal}$, whereas the continental margin is represented by $-50 \mathrm{mGal}$. It seems there is a linear relationship between both features. A gravity and seismic profile crossing the Reed Bank and the Central Basin indicate the bank is underlain by continental crust, whereas the beneath the basin is oceanic ${ }^{[11,12,13]}$; and 3) the Palawan and Nansha Basin are represented by free-air anomaly of $-80 \mathrm{mGal}$. 
$\mathrm{Ru}$ and Pigott (1986) ${ }^{[14]}$ suggested the tectonic element of SCS is to consist of 1) the active Manila Trench; 2) the non active Palawan Trench, the Kalimantan and Palawan mélange that had been exposed because of a subduction process and centers of spreading in the bottom of the South China Sea Basin (Figure 3).

The rifted passive continental margin indicates two stages on the development of the basin had taken place. Firstly, rifting followed by spreading of the sea bottom ${ }^{[15]}$. An intercontinental rifting as one the rifting stages that was inferred being a doming up of the continental crust followed by a temperature increase in the mantle ${ }^{[16,17]}$ or by a stretching of the lithosphere ${ }^{[18]}$. The first stage of the process was characterized by a subsidence and controlled by faulting, volcanic activity (intrusions and extrusions) and a regional uplift [19]. The first stage of the spreading was marked by a break-up of the continental crust to create a new sea basin ${ }^{[16]}$, and, because of a continues sedimentation an exponentially subsidence of the bed rock had taken place ${ }^{[20]}$.

The mainland of China has been considered a micro continent drifted away during the opening of SCSB. Some sedimentary basins have been developed becoming targets for hydrocarbon exploration. These are among others Pearl River Mouth, Beibu and Yingga Seas ${ }^{[14]}$. Fracturing deceased in the Oligocene time followed by spreading and new faulting had taken place again resulted in a fracturing within the basin. The continental margin of the mainland of China and the SCS at least experienced three times of fracturing. Firstly, at the end of Cretaceous up to the Paleocene that resulted in an uplift marked by an unconformity between the Cretaceous and the Tertiary formations. This mechanism produced grabens at the end of Cretaceous and Eocene. Secondly, a fracturing was initiated in the Eocene up to Oligocene times resulted in the formation of the Reed Bank and also some small basins. Thirdly, at the end of Miocene volcanism has taken place $^{[21,22]}$.

The aim of this research is to know regionally geophysics appearance of the South China Sea structural as hydrocarbon deposits as inferred from geophysical data. The occurrences of potential hydrocarbon deposits are to be found in the continental margins of Sarawak and the Sunda Shelf, wheres the offshore region of Vietnam and Hainan are potential targets for exploration.

\section{THE CURRENT WORK}

\section{Methodology}

The data analyses were done on existing data, such as free-air gravity, total magnetics, some reflection seismic and heat flow. The free-air anomaly of Bowin, et al. (1982) [9] were digitized and re-contoured. Bouguer values were calculated from this digitized freeair values.

Derivative maps such as residuals are generated from the digitized data. Four gravity models of $2.5 \mathrm{D}$ were made, one line parallel to the strike direction of anomaly, whereas the other three across perpendicularly to the general trend of the anomaly contours.

The magnetic data were obtained from "Magnetic Anomaly Map of East Asia", Geological Survey of Japan, (1994) ${ }^{[23]}$ in the form of digitized data of 10 - 4 degree grid size with an accuracy of $0.1 \mathrm{nT}^{[24]}$. These data were re-processed by digitizing at $500 \mathrm{~m}$ interval to be generated a total magnetic map (Figure 7). 
The reflection seismic data were taken from existing report, whereas refraction seismic was based on the report of Houtz and Hayes (1984) ${ }^{[25]}$. Because raw data of seismic and heat flow were not available, only a careful evaluation was conducted.

\section{The Free-Air Anomaly Map}

Free-air anomaly map generated from the digitized "Free Air Gravity of the World" [9] (Figure 4). The SCSB is bordered by -25 to $-50 \mathrm{mGal}$ in the north-west, the eastern part is in coincident with the Manila Trench inferred being an active subduction zone, whereas in the southeast and in the south by 25 up to $50 \mathrm{mGal}$. The Palawan basin is marked by a low anomaly of $25 \mathrm{mGal}$. A high anomaly of $100 \mathrm{mGal}$ is observed in the Reed Bank. Quite a number of low irregular rounded anomalies are found in the SCSB being inferred as undulations of bathymetry most likely caused by faulting system resulting mini grabens formation. The Suna Shelf is represented by anomalies ranging between 25 and $50 \mathrm{mGal}$. The Zengmu or the Serawak Basin in the northern portion of the Sunda Shelf forms a boundary of the continental and oceanic crust with small anomaly of 10 to $20 \mathrm{mGal}$. Some portion of the continental crust bulging in the Zengmu Basin forming several horsts.

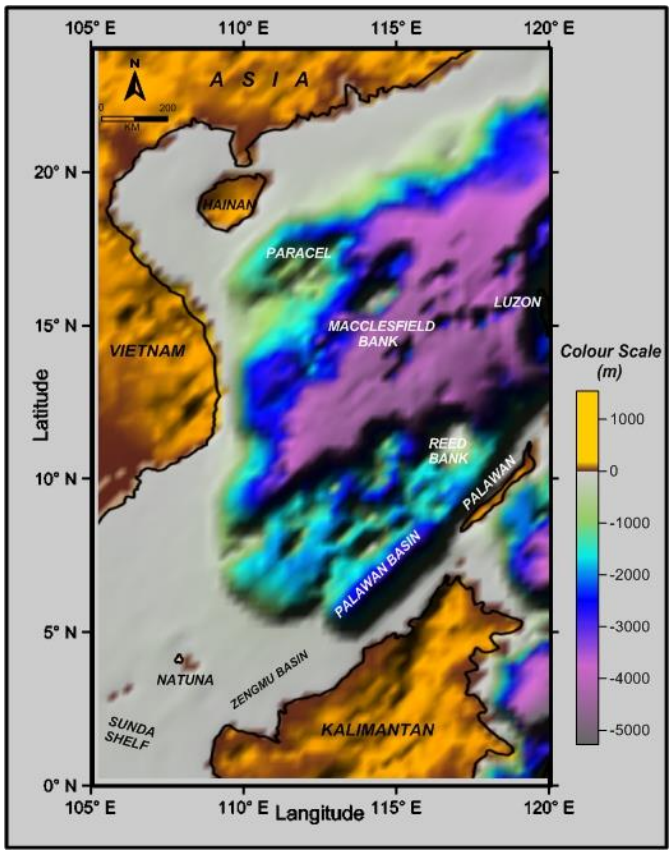

Figure 3. Bathymetry map of the South China Sea (Taylor and Hayes, 1980) ${ }^{[27]}$.

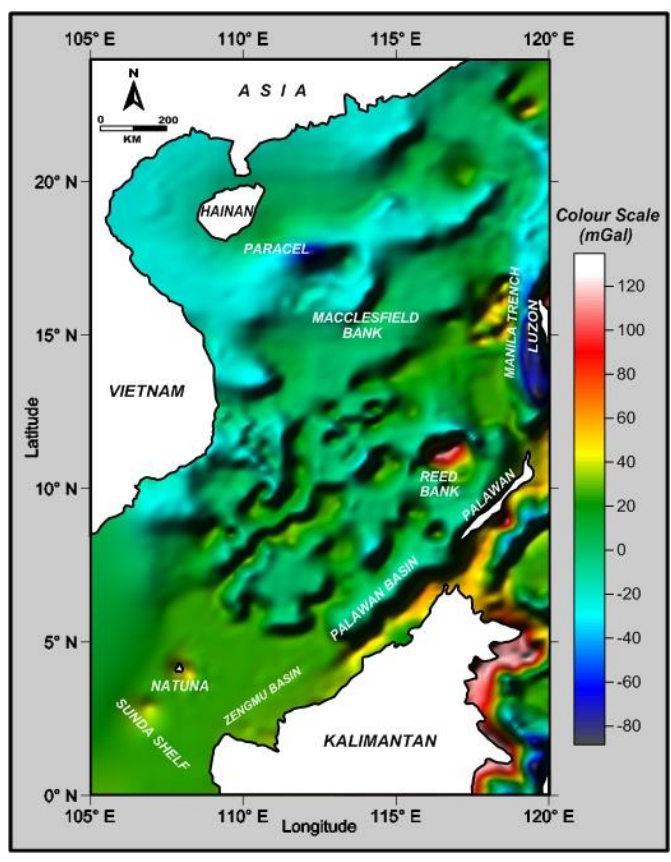

Figure 4. Free-air anomaly map. Modified from Bowin, Warsi and Milligan ${ }^{[9]}$.

\section{The Bouguer Anomaly}

The Bouguer values were derived from the Free-air values using the simple formula ${ }^{[26]}$ :

$$
\begin{aligned}
\mathrm{BA}=\mathrm{FAA}- & \{-2 \pi \mathrm{G}(2.67-1.03)\} \mathrm{h}(\mathrm{mGal}) \\
\mathrm{BA} & =\text { Bouguer Anomaly } \\
\mathrm{FAA} & =\text { Free-Air Anomaly } \\
\mathrm{G} & =\text { Gravitational Constant }\left(6.67 \times 10^{-8}\right) \\
2.67 & =\text { Crustal density },\left(\mathrm{g} / \mathrm{cm}^{-3}\right) \\
1.03 & =\text { Sea water density },\left(\mathrm{g} / \mathrm{cm}^{-3}\right) \\
\mathrm{h} & =\text { Depth of sea bottom },(\mathrm{m})
\end{aligned}
$$


Figure 5 are respectively map of Bouguer values with contour interval $25 \mathrm{mGal}$. As shown the anomaly values range between 0 to $50 \mathrm{mGal}$ located in about the outer margin and 300 to $350 \mathrm{mGal}$ in the basin. The general trend of this anomaly determines the shape of the basin which is more or less elliptical stretching from the latitudes $200^{\circ} \mathrm{N}$ in the northeast and $120^{\circ} \mathrm{N}$ in the southwest. This large anomaly is referred as an active spreading center during the Oligocene and Miocene time. A very steep gradient of $3 \mathrm{mGal} / \mathrm{km}$ that forms the outer margin of the SCSB is thought to be the boundary between the continental and oceanic crust. The Reed Bank is represented by anomalies between 100 and $150 \mathrm{mGal}$ is interpreted being underlain by a continental crust with densities 2.67 and $2.85 \mathrm{~g} / \mathrm{cm}^{3}$ of 20 $\mathrm{km}$ thick overlain by sediments of density $2.10 \mathrm{~g} / \mathrm{cm}^{3}$ of $4.0 \mathrm{~km}$ of thickness.

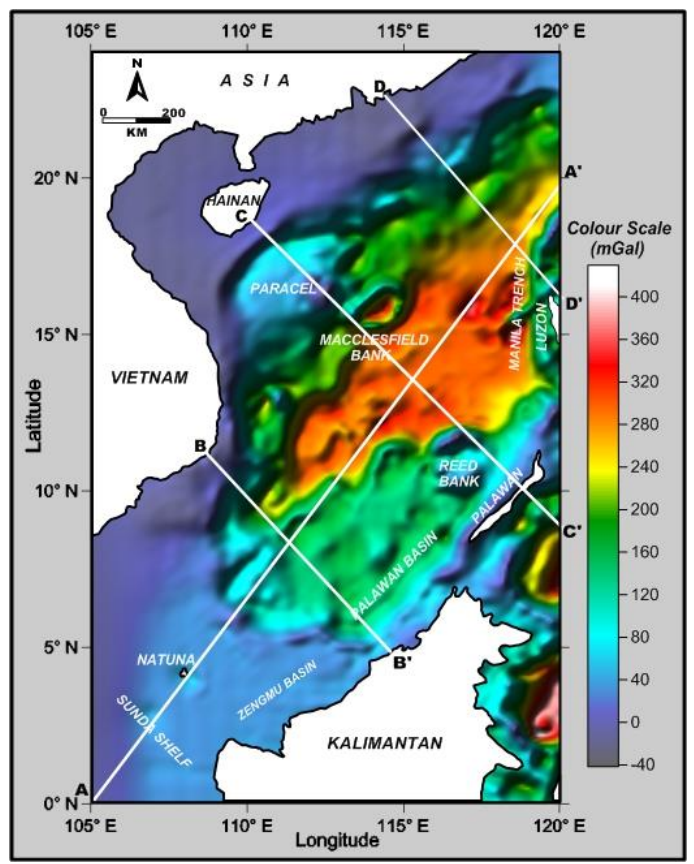

Figure 5. Bouguer anomaly map. A-A', B- B', C-C and $\mathrm{D}^{-\mathrm{D}^{\prime}}=$ gravity model sections (Figs.11, 12, 13 and 14).

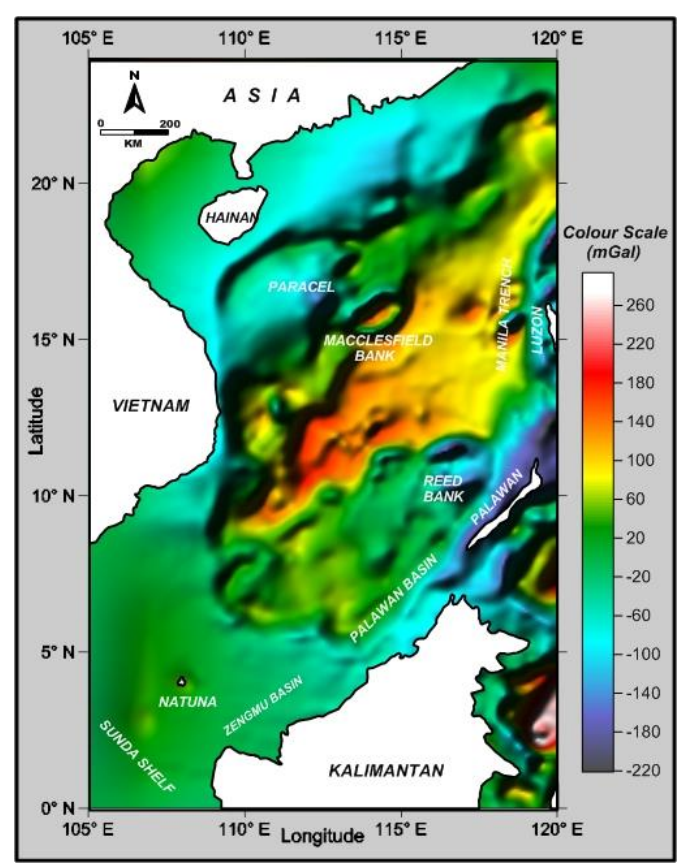

Figure 6. Residual Bouguer map of the 3 order.

The Palawan Basin with it's 50 to $100 \mathrm{mGal}$ is inferred as a non-active subduction. More to the north a gradient of $2.5 \mathrm{mGal} / \mathrm{km}$ is encountered which is in coincident with the active Manila Trench. The Bouguer anomaly shows clearly a gravity high in the order of $150 \mathrm{mGal}$ an expression of an area triangle in shape that borders a high anomaly in the west that is the deepest part of the SCSB (Figure 5). Here, the sediment is thin which is about $2.0 \mathrm{~km}$ thick, underlain by a thick crust of 12 to $16 \mathrm{~km}$. This part is named by $\mathrm{Ru}$ and Pigott (1986) ${ }^{[14]}$ as Southwest Subbasin as demonstrated clearly by the third order of residual gravity (Figure 6). Towards the southeast from the Southeast Subbasin Bouguer anomaly in the order of 250 to $300 \mathrm{mGal}$ representing another basin named by $\mathrm{Ru}$ and Pigott (1986) ${ }^{[14]}$ as East Subbasin.

\section{The Total Magnetic Anomaly}

The original data is the Magnetic Anomaly map of East Asia (Geological Survey of Japan, 1994) ${ }^{[23]}$. The area that covers the area of investigation was re-digitized to generate a total magnetic map of $25 \mathrm{nT}$ contour interval (Figure 7). 


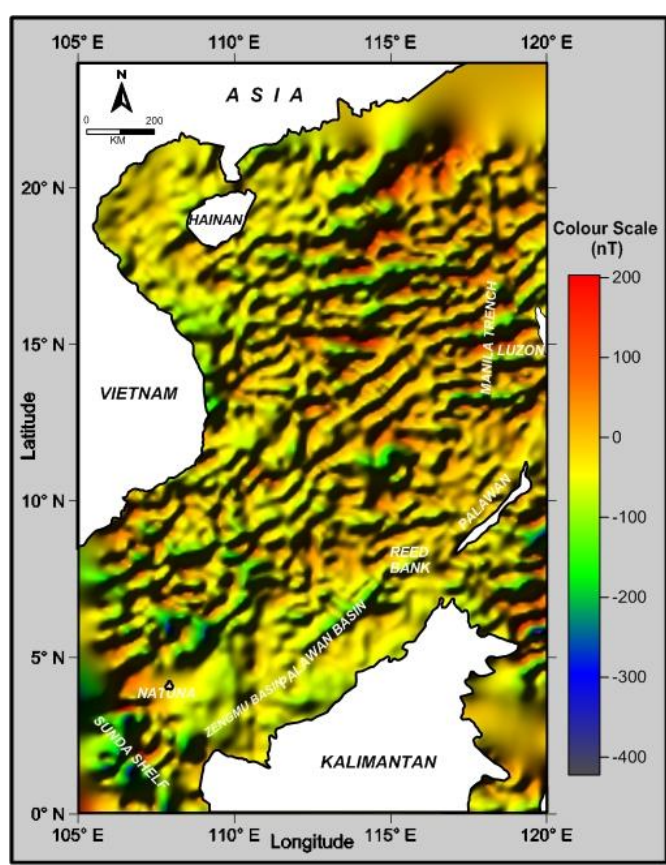

Figure 7. Total magnetic $(\Delta \mathrm{T})$ map. E-W trending lineations are common. A SW-NE pair of anomaly is inferred being a part of a spreading centre. Source of digital magnetic data : "Magnetic Anomaly Map of East Asia", (1994) ${ }^{[23]}$

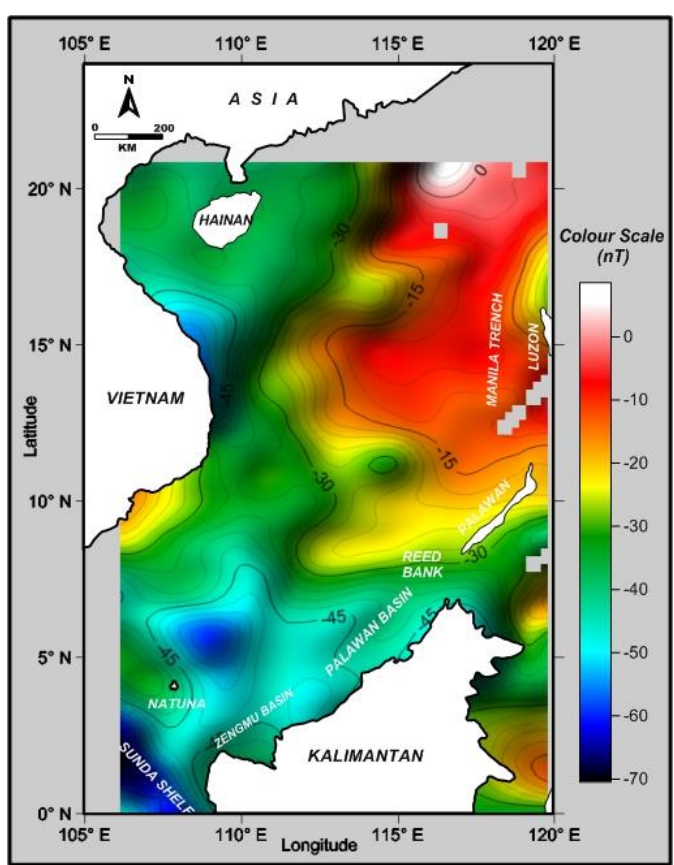

Figure 8. Total Magnetic $(\Delta \mathrm{T})$ map of $1000 \mathrm{~m}$ upward continuation.

As shown a dense high frequency of east-west regular lineation covers most part of the investigated region. In the northeastern part a group of relatively high anomaly is inferred being underlain by a magnetic basement belonging to the oceanic crust. This situation is also shown by the $1000 \mathrm{~m}$ upward continuation map (Figure 8) where high anomaly is found on the same location.

This map discards the high frequency anomalies and leave the low frequencies of long wavelength indicating deep and broad structural configuration. A feature at the center of SCSB located approximately at the longitude $115^{\circ} \mathrm{E}$ and latitude $14^{\circ} \mathrm{N}$ in the northeast and $110^{\circ} \mathrm{E}$ and $9^{\circ} \mathrm{N}$ in the southwest is interpreted being remnant of a seafloor spreading which was very active du ring the Oligocene and terminated in the Miocene ${ }^{[4,14,24,27]}$. The general trend of this spreading is southwest-northeast (Figure 9). Starting from this point the micro continent of South China were separated; China to the northwest and Kalimantan to the southeast. Kalimantan which was rotated counterclockwise in the Mesozoic was reactivated during the Oligocene and terminated in the Miocene time and retained at the present position ${ }^{[28,29,30]}$. 


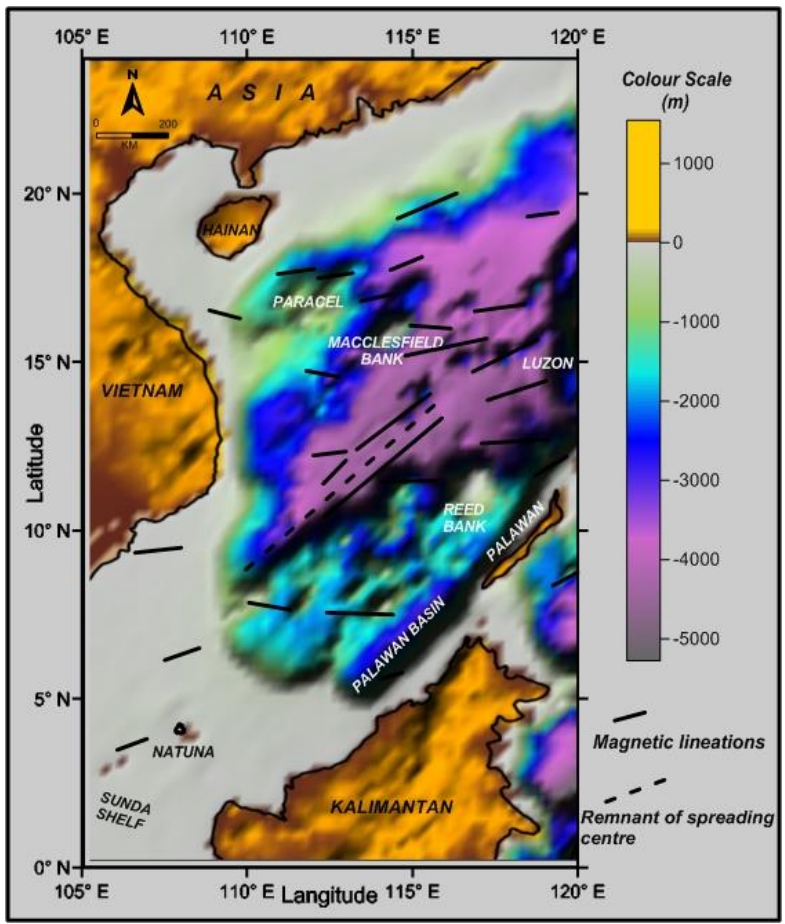

Figure 9. Interpretation map of magnetic lineations

\section{Seismics}

Some single channel surveys that were done earlier did not reach the basement rock except the multichannel survey in the Palawan Basin. These seismic data provide a very useful clue to model the gravity data. The morphology of the sedimentary rock formation controlled by normal faults are shown very clearly. Figures 4 and 8 in Taylor and Hayes (1980, p. 93 and 102) ${ }^{[4]}$ resemble the gravity model which will be discussed in a later section of this report. A refraction seismic profile in the Serawak Basin shows depth of the crustal rock about $1.5 \mathrm{~km}$ in the west and 5.0 in the east of the basin ${ }^{[25]}$.

\section{Heat Flow and Seismicity}

The heat flow in the Asian region could be classified into the following ${ }^{[31]}$ : a) the region between the axis of a trench and a volcanic belt is represented by an average heat flow value lower than $1 \mathrm{HFU}$; b) a volcanic belt of high value (2 HFU and higher); and c) the back arc basin of average value between 1 and 2 HFU. In the survey area heat flowvaries between 1.5 to 3.5 HFU (Figure 10) ${ }^{[14]}$. The lowest heat flow value is in the active subduction zone of the Manila Trench and also in the Palawan Basin a remnant of a past subduction. High heat flows in the order of 2 to $3.5 \mathrm{HFU}$ are observed at the center of SCSB that coincide with traces of an extinct subduction during the Oligocene up to the Miocene time. The occurrence of seamounts strengthens the existence of the past seafloor spreading. High heat flow of 2 to $10 \mathrm{HFU}$ are observed east of Luzon continues to the north reaching the offshore region east of Taiwan. This pattern coincides with the high seismicity of the North Luzon Trough. The subduction in the Manila Trench resulted in a high seismicity underneath the Luzon Island. A profile from west of the SCSB towards the east crossing the Philippines (Figure 2) ${ }^{[7]}$. The active subduction in the Manila and the Luzon Trench are expressed by low free-air and magnetic anomalies and also by small heat flow. These two trenches are related closely to the volcanic activity and seismicity in Luzon. 


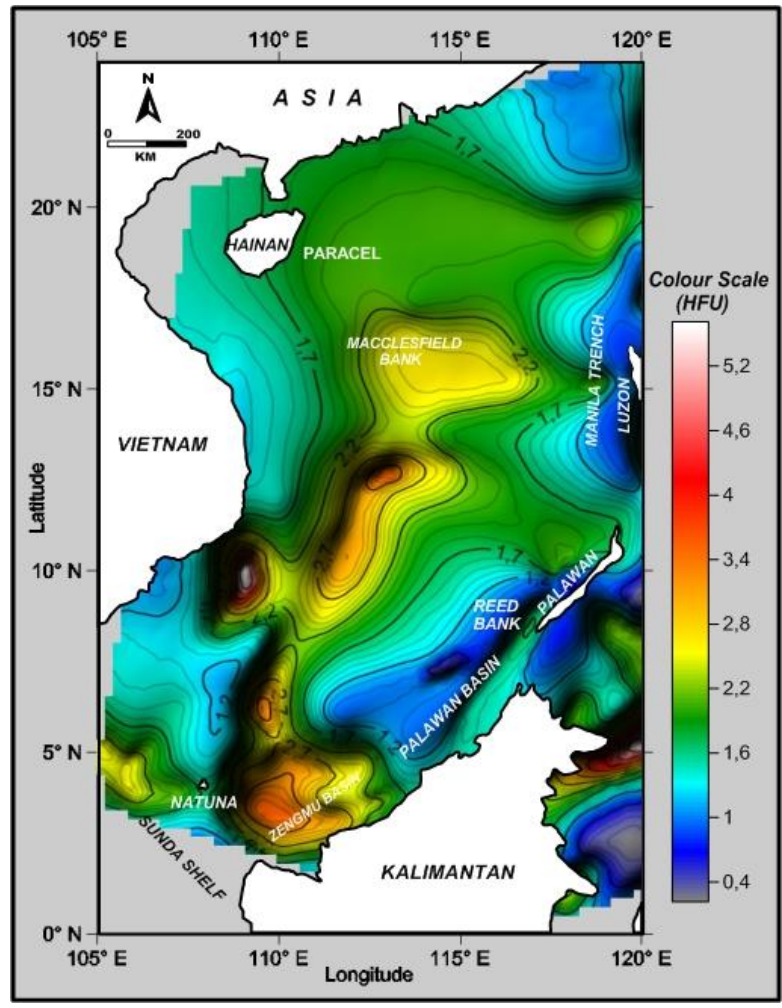

Figure 10. Heat flow map in HFU.

The Manila trench and the Palawan basin are represented by low heat flow values (1 - $2 \mathrm{HFU})$. Higher heat flow values (2 - $3 \mathrm{HFU})$ are at the centre of the basin. Very high heat flow values ( $3-10 \mathrm{HFU}$ ) are observed along the trench east of the Filippines ${ }^{[14]}$.

\section{GRAVITY MODELING}

The crustal structures were modeled based on the Bouguer anomalies. The structural models were made along four sections namely A-A', B-B', C-C' and D-D' (Figures. 11, $12,13,14)$. Except A-A', the other three sections are almost perpendicular to the general trend of the gravity and Bouguer anomaly. The simple 2.5D gravity program of Talwani was used based on background density of $2.85 \mathrm{~g} / \mathrm{cm}^{3}$. The modeling was controlled by seismic data, heat flow, magnetic data and the general tectonic of the region. The basic philosophy of the modeling is that the South China Sea (SCS) is underlain by sediments, crustal rock and the upper mantle. Occurrences of fractures followed by spreading and extensions, and, subsidence result in a faulting system, especially normal faults. The Mesozoic up to the Quaternary are heavily faulted.

The profile A-A' crosses the SCS as long as $2400 \mathrm{~km}$ from the Sunda Shelf in southwest towards Luzon in the northeast (Figure 11). As shown the subsurface structure is much simplified. The various sedimentary column is assumed having the same density, that is $2.10 \mathrm{~g} / \mathrm{cm}^{3}$, an average density value of the Mesozoic up to the Quaternary rock formation, seawater $1.03 \mathrm{~g} / \mathrm{cm}^{3}$, upper crust $2.67 \mathrm{~g} / \mathrm{cm}^{3}$, lower crust $2.85 \mathrm{~g} / \mathrm{cm}^{3}$ and the upper mantle $3.30 \mathrm{~g} / \mathrm{cm}^{3}$. The Zengmu or the Sarawak Basin is underlain by thick sediments and crustal rock which is in contradiction with Xia Kan-Yuan postulation (1995) ${ }^{[6]}$. Here, the Mohorovicic discontinuity is very deep. At the central part of the SCSB the water depth is maximum which is about $4 \mathrm{~km}$, whereas the sediments become thinner so does the crustal rock and thickens again in the northeast. The lower crust and the upper mantle behave a 
dome-shaped structure at the center of the SCSB producing high Bouguer and low free-air values.

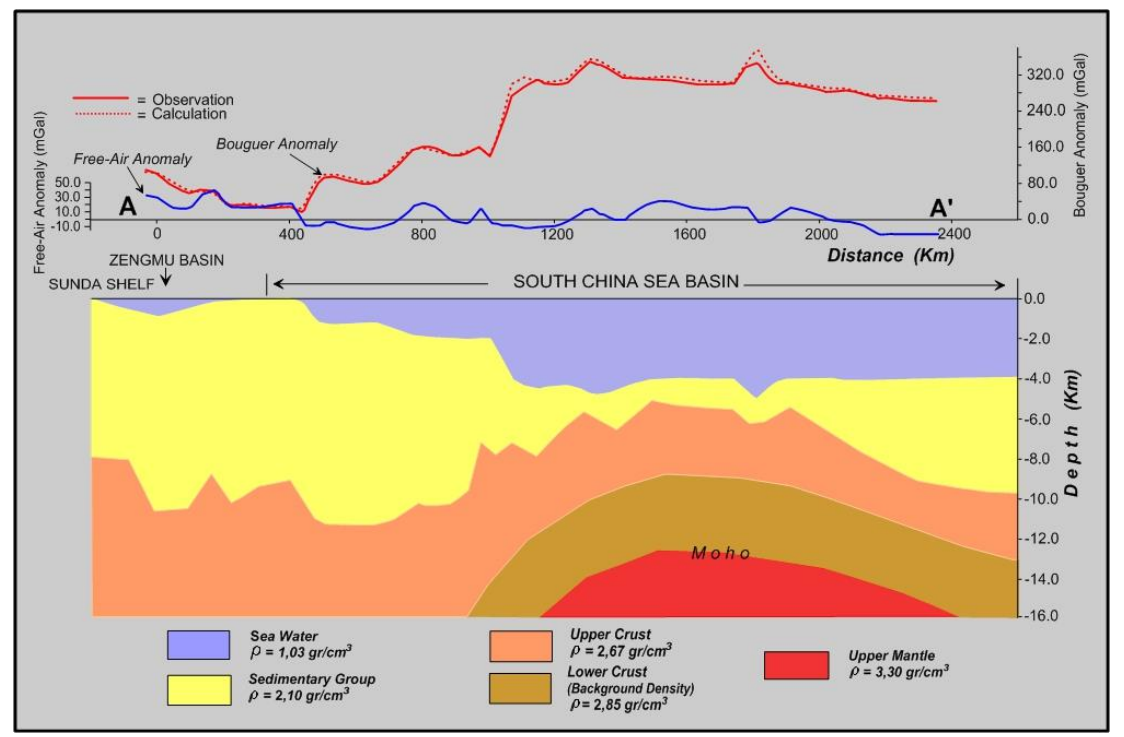

Figure 11. Crust structural model A - A' ( Figure 5). The sediment density $2.10 \mathrm{~g} / \mathrm{cm}$ is a mean density of various sedimentary formation in the region.

The Moho depth is about $13 \mathrm{~km}$ at the center of the basin and deeper, about $22 \mathrm{~km}$, in the northeast. The crest of the lower crust and the upper mantle may depict remnant of spreading center. This is clearly shown by the $950 \mathrm{~km}$ profile B-B' that crosses the basin from the coastal plain of Vietnam in the northwest towards the coastal plain of Kalimantan in the southeast (Figure 12). There is no prominent undulation of the sedimentary formation, but deformation in the upper crust is very dominant and therefore significant as far as the tectonic history is concerned. The crustal rock offshore Vietnam is covered by about $8 \mathrm{~km}$ thick sediments and thinning towards the center of the basin. High frequencies of magnetic anomaly may indicate an occurrence of high polarized magnetic basement. The Bouguer and the magnetic anomalies could be interpreted being a reflection of a fossilized spreading center about the center of the basin. Taylor and Hayes (1980) ${ }^{[4]}$ estimated this spreading was active in the Oligocene until the upper Miocene time. The numerous occurrences of normal faults in the basin may indicate the basin must be a giant graben. 


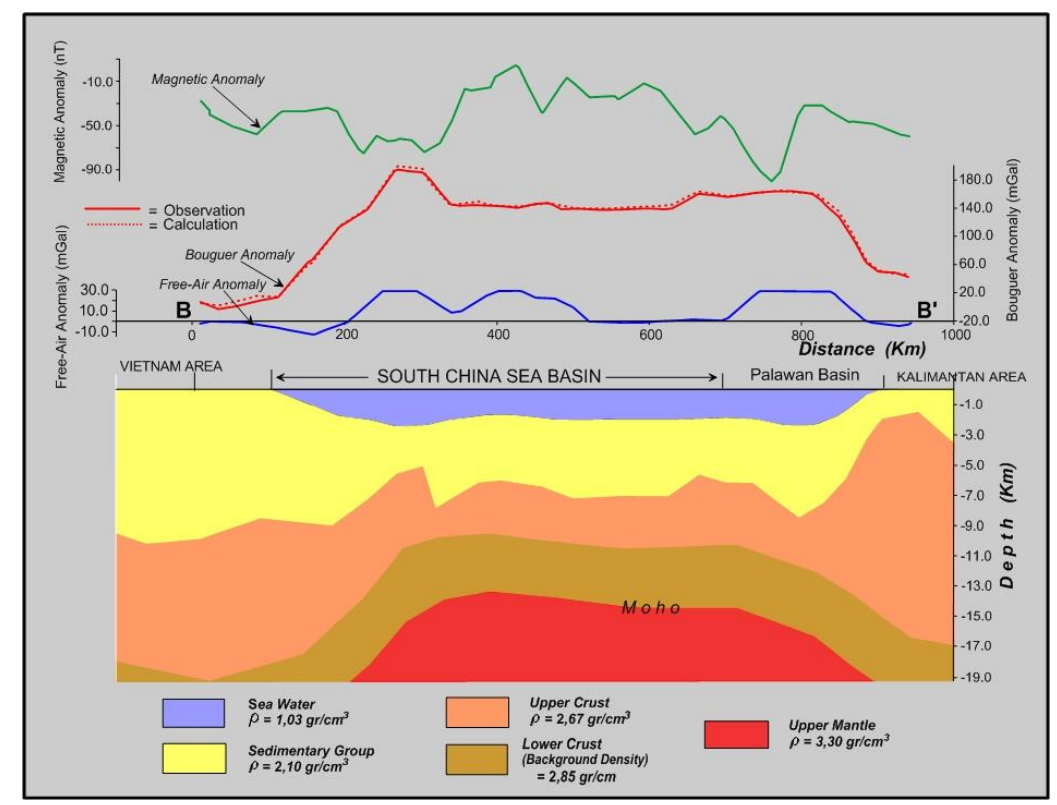

Figure 12. Crust structural model B-B' (Figure 5). The sediment density $2.10 \mathrm{~g} / \mathrm{cm}$ is a mean density of various sedimentary formation in the region.

The C-C' section is $1600 \mathrm{~km}$ long from the coastal plain of Hainan in the northeast passing the Paracel islands and the southern part of Macclesfield Bank and the Reed Bank until the Palawan Island in the southeast (Figure 13). Again, the structural setting is the same as underneath section B-B'. Remnant of spreading is clearly defined at the center of the basin as inferred mainly by the magnetic data. The high frequency of the magnetic data and their rapid polarization coincide with the ridge of the crust of $2.67 \mathrm{~g} / \mathrm{cm}^{3}$ density. A thickening of sediments is encountered underneath the Paracel islands that has been uplifted and exposed at the water surface. This condition also happens with the Reed Bank and the Palawan Island. Reed Bank is underlain by an uplifted upper crust of $2.67 \mathrm{~g} / \mathrm{cm}^{3}$ density. The majority of rock formation in the Palawan Island is a mélange that was formed during the Oligocene until the Miocene subduction along the Palawan trench.

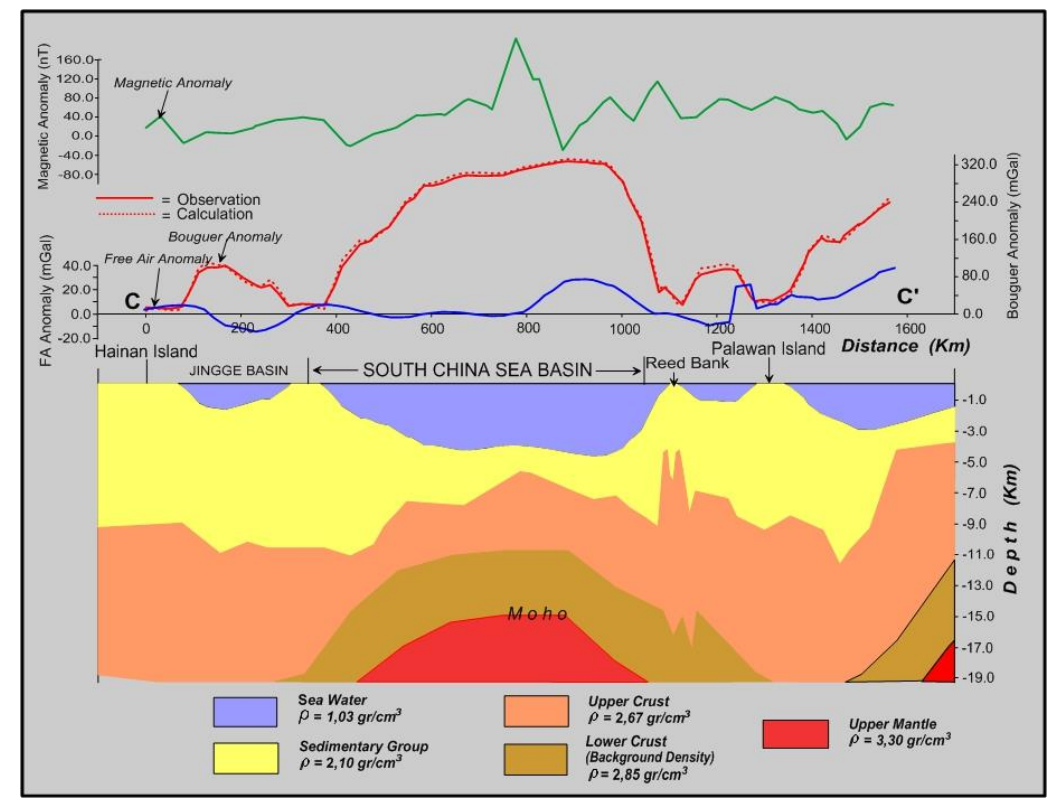

Figure 13. Crust structural model $\mathrm{C}^{-\mathrm{C}^{\prime}}$ (Figure 5). The sediment density $2.10 \mathrm{~g} / \mathrm{cm}$ is a mean density of various sedimentary formation in the region. 
The last section is D-D' of $950 \mathrm{~km}$ long started from the coastal plain of the mainland China in the northwest towards the coastal plain of Luzon in the southeast (Figure 14). The Pearl River Mouth Basin with its thick sedimentation is thought having a large hydrocarbon potential. Here, the seawater depth varies between 100 up to 200 meters, whereas the sedimentary thickness is between 4 and $8 \mathrm{~km}$. The age of the sediments is Mesozoic until the Quaternary and is heavily faulted. Towards the southeast the sediments become thinner (about $4 \mathrm{~km}$ at the center of the basin). The Manila Trench with it's active subduction in the utmost end of the profile is marked by an almost vertical escarpment of 4 $\mathrm{km}$ throw that could be interpreted as a normal fault. The Moho depth underneath this section ranges between 15 to $17 \mathrm{~km}$.

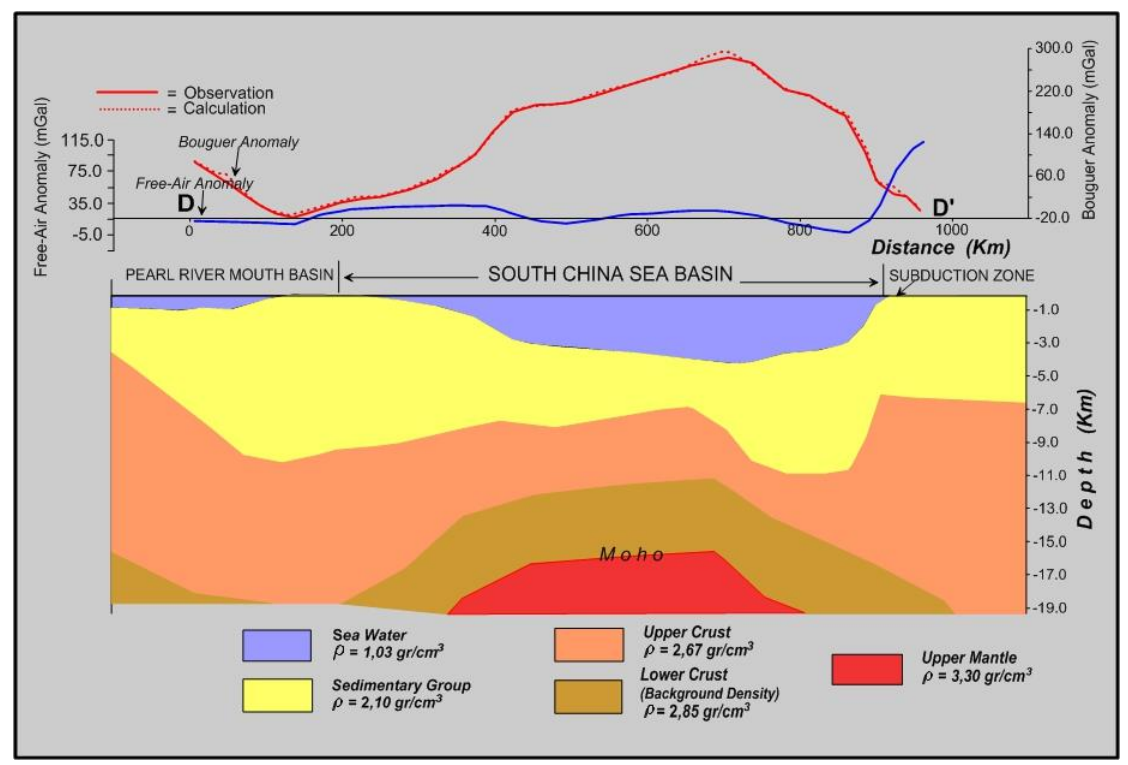

Figure 14. Crust structural model D-D' (Figure 5). The sediment density $2.10 \mathrm{~g} / \mathrm{cm}$ is a mean density of various sedimentary formation in the region.

\section{ANALYSES AND INTERPRETATION}

Based on the results of the gravity and magnetic data strengthened by seismic data and heat flow a reconstruction of South China Sea (SCS) was made (Figure 15).

At the end of the Cretaceous time the SCS region was uplifted followed by seafloor spreading in late Oligocene time resulted in a push of the micro continent of China and Kalimantan respectively to the northwest and southeast. This spreading resulted in a rifting and followed by extension and simultaneously a subsidence took place and finally the SCSB was formed. This spreading continued until the Miocene and positioned Kalimantan as it is today. An uplift at the center of the basin has been active again leading to a formation of a horst. 


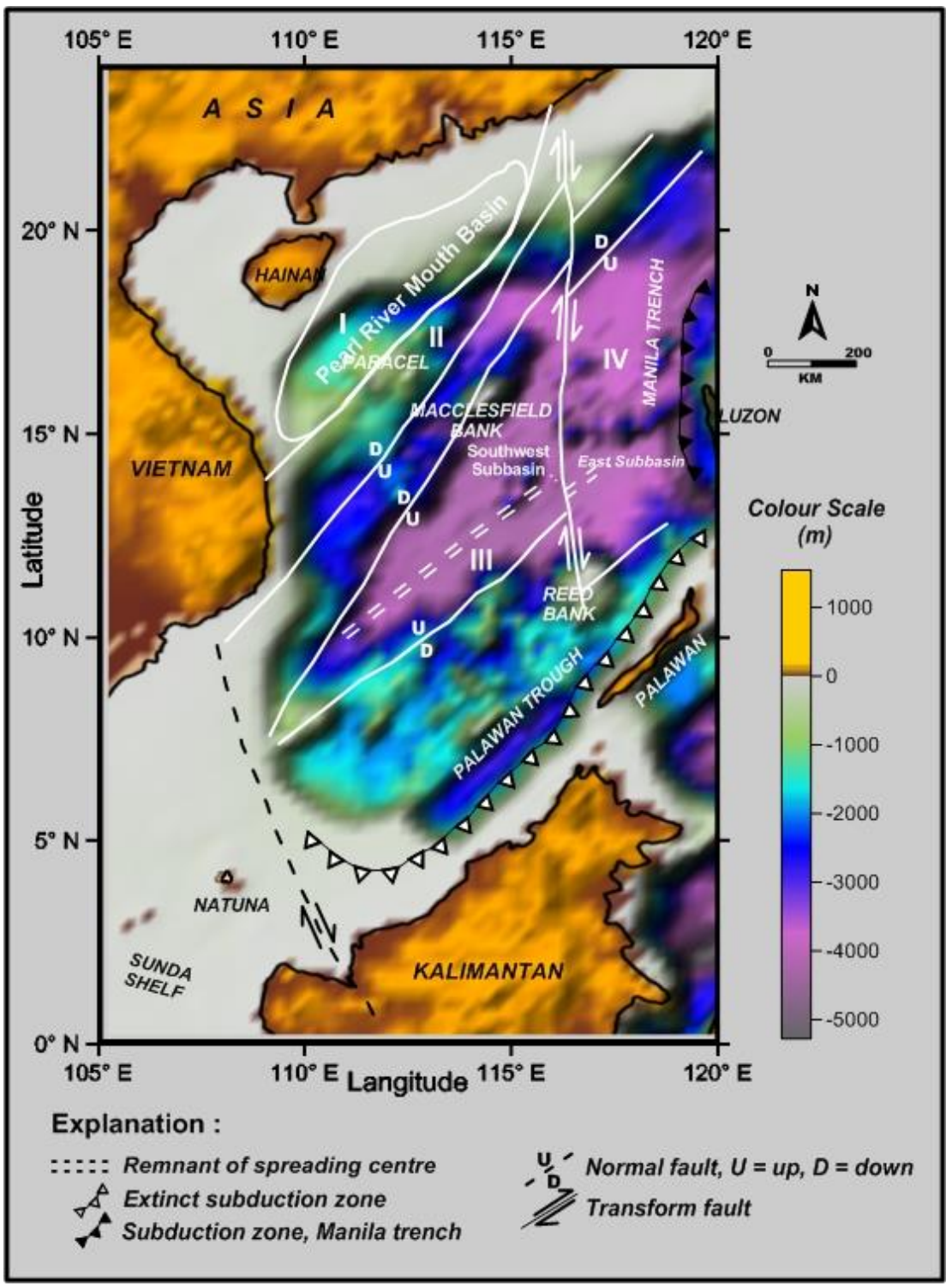

Figure 15. Basinal structural pattern of the upper crust $\left(2,67 \mathrm{~g} / \mathrm{cm}^{3}\right)$ Block I overlain by sediments of $5-8 \mathrm{~km}$ thickness. Block II overlain by sediments of $5 \mathrm{~km}$ thickness. Block III overlain by sediments of $2-3 \mathrm{~km}$ thickness. Block IV overlain by sediments of $4-5 \mathrm{~km}$ thickness.

The SCS is most likely built up by four provinces called as Blocks (Figure 15). Block III located at the middle of the basin is supposed the largest in size ${ }^{[32]}$. The seawater is the deepest underlain by a 2 to $3 \mathrm{~km}$ thick sediment and a relatively thin crust. Block I cover the Pearl River Mouth Basin, a local depression in the continental margin. This block is the site of the mouth (lower course) of rivers in China and Hainan. The sedimentary sequence in this basin is about 5 to $8 \mathrm{~km}$ thick which is considered being potentially rich in hydrocarbon accumulation. Block II is a steep vertical gradient as long as $256 \mathrm{~km}$ trending north-northeast that is inferred as the boundary region between the continental and oceanic crust. The sediment is about $5 \mathrm{~km}$ thick underlain by $5 \mathrm{~km}$ thick of the upper crust. This block is separated from Block III by a normal fault that covers an elongated trending region of $1600 \mathrm{~km}$ long. Within Block II faulting is very intensive. One of them is a normal fault parallel to the fault that separates Block II from Block III mentioned earlier. This fault seems to divide Block II into two sectors. Block IV is separated from 
Block III by a strike-slip fault that was generated after the normal faults in Block II and III were formed. The sedimentary column in this block varies between 4 to $8 \mathrm{~km}$, whereas the crustal thickness reaches $12 \mathrm{~km}$. To the east of this block a very steep gradient Bouguer anomaly may indicate the boundary between the SCSB and the Manila Trench. High magnetic anomalies occupy this block that might represent a magnetic basement at a relatively shallow depth (Figure 8). The subduction in the Manila Trench generates volcanism and high seismicity in the island of Luzon.

\section{CONCLUSIONS}

The tectonic of SCS was active since the Cretaceous time, then became a passive basin since the termination of the sea floor spreading in early Miocene that was started in late Oligocene. Normal faulting was active during the spreading period followed by extension of the region and also subsidence to form the SCSB that was marked by high Bouguer anomaly and fluctuation of free-air anomalies.

The magnetic anomaly shows very distinct indication of the occurrence of remnant of a seafloor spreading. Heat flow values are relatively high varying between 2 and 3.5 HFU.The basin is bordered by $200 \mathrm{~m}$ bathymetry contour which is in coincidence with 50 mGal Bouguer contours. Several strike-slip faults were active after the normal faulting ceased. The Manila Trench a zone of active subduction west of Luzon is expressed by steep gradient of free-air and Bouguer and low heat flow values that vary between 1 and 2 HFU. This active subduction is responsible for the volcanism and seismicity in Luzon.The offshore region of Vietnam and Hainan is a potential target for hydrocarbon exploration.

\section{ACKNOWLEDGEMENT}

The authors would like to thank Dr. Takemi Ishihra of the Insititute for Marine Resources and Environment, National Institute of Advanced Industrial Science and Technology for his kindness of generously granting digital magnetic data of the whole South China Sea. To the Geophysics Division of MGI the authors extend their gratitude for the permission of using the computer facilities.

\section{REFERENCES}

1 Karig, D.E. 1971. Origin and Developmen of Marginal Basins in the Western Pacific. Journal of Geophysical Research, 76, 2543-2561.

2 ---------. 1973. Plate Convergenc between the Philippines and the Ryuky Islands. Marine Geology, 14, 53-168.

3 Qin Xu-wen, Zhao Bin, Li Fu-yuan, Zhang Bao-jin, Wang Hou-jin, Zhang Ru-we, Hec Jia-xio and Chen Xi. 2019. Deep Structural Research of The South China Sea: Progresses and Direction, China Geologi Journal, China Geolgical Survey, 2 (4), 530540, http://chinageology.cgs.cn.

4 Taylor, B. and Hayes, D.E. 1980. The Tectonic Evolution of the South Cina Sea Basin, The Tectonic and Geologic Evolution of Southeast Asian Seas amd islands. Geophys. Monograph, American Geophysical Union, 23, 89-104.

5 Hall Robert and Breitfeld H. Tim. 2017. Nature and Demise of the Proto-South China Sea. Bulletin of the Geological Society of Malaysia, 63, 61-76.

6 Xia Kan-Yuan and Zhou Di. 1995. The Geophysical Characteristics and Evolution of Northern and Southern margins of the South China Sea. Geol. Soc. Malaysia, Bull., $33,225-240$. 
7 Studies in East Asian Tectonics and Resources (SEATAR). 1980. Banda Sea, CCOP Project Office.

8 GETECH (Geopphysical ExplorationTechnology) and IGC (Indonesian Gravity Commission). 1995. South-East Asia Gravity Project, GETECH Technical Report.

9 Bowin, C., Warsi Waris and Milligan, J. 1982. Free-Air Gravity Anomaly Atlas of the World. Geological Society of America Map and Chart Series, No. Mc-46.

10 Su Da Quan, Chen Xue and Liu Zu Hui. 1995. The Gravity Field and Tectonics of the Nansha Islands (Dangerous Ground). Proceedings AAPG-GSM Conference 1994, Southeast Asian Basins: Oil and gas for the 21st Century, Kuala Lumpur, Malaysia, Geological Society of Malaysia, Bulletin 37, 117-123, Ed. G.H. Teh.

$11 \mathrm{Su}$, Daquan and Huang Ciliu. 1987. A Study on the Gravity Field of Nansha Sea Area. Tropic Oceanology, 6 (4), 10-18.

12 --, -----, White, N. and McKenzie, D. 1989. Extension and Subsidence of the Pearl River Mouth Basin, Northern South Cina Sea. Basin Research, 2, 205-222.

13 --, ------, Liu Zuhui and Chen Xue. 1991. Gravity Field in Reed Bank and Its Vicinity, Ocean Publishing House (in Chinese).

$14 \mathrm{Ru}, \mathrm{KE}$ and Pigott, J.D. 1986. Episodic Rifting and Subsidence in the South China Sea. AAPG Bull., 70, 1136-1155.

15 Srutton, R.A. 1982. Passive Continental Margins, A review of Observations and Mechanism, in R.A. Scrutton, ed., Dynamicsof Passive Margins. Geodynamics Series, 6, 5-11.

16 Sleep, N.H. 1971. Thermal Effect of the Formation of Atlantic Continental margins by Continental Break-up. Geophysical Journal of the Royal Astronomical Society, 24, 325-350

17 Kinsman, D.E. 1975. Sedimentary Histor of Trailing Continental Margin, in A.G Fisher and S. Judson, eds... Petroleum an Global Tectonics. Princeton, New Jersey Princeton University, Press, p. 83-126.

18 McKenzie, D. 1978. Some Remarks on the Development of Sedimentary Basins. Earth and Planetary Science Letters, 40, 25-32.

19 Burke, K., abd Whiteman, A.J. 1972. Uplift, Rifting and the Break-up of Afrika, in D.H. Tarling and S.K. Runcorn, eds. Implications of Continental Drift to the Earth Sciences, London, Academic Press, 2, 735-755.

20 Sleep, N.H. 1982. Thermal Contraction beneath Atlantic Margins, in R.A. Scrutton, ed. Dynamics of Passive Margins. Geodynamics Series, 6, 154-158.

21 Barr, S.M. and Mc Donald, A.S. 1981. Geochemistry and Geochronology of thelate Cenozoic Basalts of Southeast Asia. GSA Bulletin, 92, 1069-1142.

22 Wolfe, J.A. 1984. North Palawan Block, Philippines-Its Relation to Asian Mainland and Role in Evolution of South China Sea, Discussion. AAPG Bull., 68, 914-915.

23 Geological Survey of Japan. 1994. Magnetic Anomaly Map of East Asia, 1:4,000,000, Magnetic Anomaly Map 2. Geological Map of Japan.

24 Li Chun-Feng, Shi Xiaobin, Zhou Zuyi, Li Jiabiao, Geng Jianhua, and Chen Bing. 2010. Depth of to the magnetic layer bottom in the South China Sea area and their tectonic implications. Geophysical Journal International, 182, 1229-1247, doi: 10.1111/j.1365-246X.2010.04702. x.

25 Houtz, R.E. and Hayes, D.E. 1984. Seismic Reflection Data from Sunda Shelf. The AAPG Bull., 67 (12), 1870-1878.

26 Telford, W. M., Geldart, L. P., Sheriff, R. E., and Keys. D. A.1990. Applied Geophysics, Cambridge University Press, Cambridge. 
27 Taylor, B. and Hayes, D.E. 1984. Origin and History of the South China Sea Basin, The Tectonic and Geologic Evolution of Southeast Asian Seas and Islands, Part 2. Geophys. Monograph, American Geophysical Union, 27, 23-56.

28 Sunata, W. dan Wahyono, H. 1998. Penerapan Metode Paleomagnet untuk Rekonstruksi Pergerakan Jangka Panjang Kalimantan, Penerapan Metode Geofisika di Indonesia, 1977-1997, Edisi Pertama. Himpunan Ahli Geofisika Indonesia (HAGI), h. 45- 54, Penyunting (editor) M. Untung.

29 Schmidtke, E., Fuller, M. and Haston, R. 1990. Paleomagnetic Data from Sarawak, Malaysian Borneo and the Late Mesozoic and Cenozoic Tectonics of Sundaland. Tectonics, 9, 123-140.

30 Haile, N.S., McElhinny M.W. and McDougall, I. 1977. Paleomagnetic data and Radiometric ages from the Cretaceous of West Kalimantan (Borneo), and their significance in Interpreting Regional Structure. J. Geo. Soc. London, 133, 133-144

31 Studies in East Asian Tectonics and Resources (SEATAR). 1980. Chapter V, Reviews of Regional Research Projects and General Recommendations, Heat Flow, CCOP Project Office.

32 Ding Weiwei, and Li Jiabiao. 2016. Propagated rifting in the Southwest sub-basin, South China Sea: insights from analogue modelling. Journal of Geodynamics, Elsevier, p. 71-86.

33 Qina Xu-wen, Zhaoa Bin, Li Fu-yuan, Zhanga Bao-jin, Wanga Hou jin, Zhanga Ruwei, Hec Jia-xiong, and Chena Xi. 2019. Deep structural research of the South China Sea: Progresses and directions. China Geology, http://chinageology.cgs.cn, p. 530540.

34 Hall, R., and Breitfeld, H.T. 2017. Nature and demise of the Proto-South China Sea. Bulletin of the Geological Society of Malaysia, 63, 61-76.

35 Liua Siqing, Zhaoa Minghui, Sibuet Jean-Claude, Qiua Xuelin, Wuc Jonny, Zhanga Jiazheng, Chend Chuanxu, XueYa, and Suna Longtao. 2018. Geophysical constraints on the lithospheric structure in the northeastern South China Sea and its implications for the South China Sea geodynamics. Tectonophysics, 742-743, 101-119

36 Gozzard, S., Kusznir, N., Franke, D., Cullen, A., Reemst, P., and Henstra, G. 2018. South China Sea crustal thickness and oceanic lithosphere distribution from satellite gravity inversion. Petroleum Geoscience (PG), http://pg.lyellcollection.org/. 